\title{
ARTIKKELIT
}

\section{Muistisairaan ihmisen mielen hyvinvoinnin edellytykset - miten turvata oikeus niiden toteutumiseen?}

\author{
Sirkkaliisa Heimonen ${ }^{1}$, Anna Mäki-Petäjä-Leinonen ${ }^{2}$ \\ ${ }^{1}$ Ikäinstituutti, ${ }^{2}$ Itä-Suomen yliopisto
}

\begin{abstract}
Muistisairaus vaikuttaa sitä sairastavan ihmisen ja hänen läheistensä hyvinvointiin ja elämänlaatuun. Kognitiivisten kykyjen heikentyminen ja sosiaalisissa suhteissa tapahtuvat muutokset aiheuttavat haavoittuvuutta. Yksilöllisen tuen, laadukkaiden palvelujen ja hyvän hoivan perustana on haavoittuvuuden ymmärtäminen ja kohtaaminen. Muistisairautta sairastavan ihmisen mielen hyvinvoinnin vahvistamisen tulee olla tavoitteena tuen, palvelujen ja hoivan käytännöissä. Ammattihenkilöstöllä on keskeinen rooli mielen hyvinvoinnin edellytysten tunnistamisessa sekä niiden toteutumisessa. Tarkastelemme tässä artikkelissa muistisairaan ihmisen mielen hyvinvointia ja sen edellytysten turvaamista psykologisesta, eettisestä ja oikeudellisesta näkökulmasta. Nostamme esiin neuvonnan ja ohjauksen keskeisenä tukimuotona ja kuntoutukseen kuuluvana keinona ja pohdimme sen keskeistä merkitystä muistisairaan ihmisen mielen hyvinvoinnin vahvistamisessa.
\end{abstract}

\section{Johdanto}

Suomessa on tällä hetkellä arviolta 193000 muistisairauteen sairastunutta ihmistä, joista noin 93000 on vähintään keskivaikeassa sairauden vaiheessa. Vuosittain noin 14500 ihmistä sairastuu muistisairauteen. (Viramo \& Sulkava 2015.) Muistisairautta sairastavien ihmisten itsemääräämisoikeuden ja heidän yhdenvertaisen kansalaisuutensa turvaaminen on yhteiskunnan tärkeä tehtävä. On panostettava siihen, että he voivat elää tasavertaisina yhteisön jäseninä ja saada tarvitsemaansa tukea ja palveluja. (STM 2012.) Muistisairaan ihmisen hyvinvointia, elämänlaatua ja toi- mintakykyä voidaan tukea kokonaisvaltaisella kuntoutuksella, jossa ohjaus ja neuvonta ovat keskeisessä roolissa koko sairausprosessin ajan (Pirttilä 2004; Huhtamäki-Kuoppala, Ekola \& Hallikainen 2015). Yksilöllisiin tarpeisiin oikea-aikaisesti vastaavalla ohjauksella ja neuvonnalla tuetaan muistisairauteen sairastuneen ihmisen mielen hyvinvointia ja turvataan sen edellytysten toteutuminen. Tuen tarpeita on tärkeää tarkastella myös mahdollisten läheisten näkökulmasta (ks. Eloniemi-Sulkava ym. 2006).

Gerontologian kentässä on viime vuosina yhä enenevässä määrin tarkasteltu ikäihmisen mielen hyvinvointia ja jäsennetty siihen vai- 
kuttavia tekijöitä (Cattan 2009; Heimonen \& Pajunen 2012; Saarenheimo 2013; Haarni 2014). Muistisairauteen sairastuneiden ihmisten mielen hyvinvointi ja sen tukemisen keinot ovat myös vähitellen nousseet keskiöön (Eloniemi-Sulkava \& Savikko 2011; Clarke \& Wolverson 2016), ja psykososiaalisten tukimuotojen kehittämisen tarve on tunnistettu (Moniz-Cook \& Manthorpe 2008).

Mielen hyvinvointia voidaan lähestyä myös oikeustieteen näkökulmasta. Tällöin keskeistä on kysymys siitä, löytyykö lainsäädännöstämme sellaisia sääntöjä ja periaatteita, jotka kiinnittyvät mielen hyvinvoinnin edellytyksiin. Edelleen voidaan tarkastella, minkälaisen välineen mielen hyvinvoinnin edellytysten oikeudellinen tarkastelu voi tarjota sosiaali- ja terveydenhuollon kentällä toimivalle ammattihenkilölle.

Tarkastelemme tässä artikkelissa muistisairaan ihmisen mielen hyvinvointia psykologisesta, eettisestä ja oikeudellisesta näkökulmasta ja esitämme, että näiden näkökulmien yhdistäminen luo mielen hyvinvoinnin edellytysten turvaamiseen vankan perustan. Artikkelin tavoitteena on tuoda uutta tietoa ja näkökulmia keskusteluun siitä, miten muistisairaiden - tai ylipäätään haavoittuvien - ihmisten oikeus hyvään kohteluun turvataan. Vaikka tarkastelun keskiöön on tässä artikkelissa nostettu muistisairaat ihmiset erityisen haavoittuvana ryhmänä, kysymys on laajempaakin ihmisryhmää koskevista havainnoista. Artikkelissa pohditaan, miten mielen hyvinvointia voidaan turvata ja miten oikeusjärjestelmämme sitä tukee.

Tarkastelemme seuraavassa luvussa mielen hyvinvoinnin käsitettä ja lähtökohtia psykologisesta näkökulmasta. Tuomme esille, millä tavoin muistisairaan ihmisen mielen hyvinvointia on tarkasteltu kirjallisuudessa. Tämän jälkeen avaamme lainsäädännön keinoja mielen hyvinvoinnin edellytysten tarkasteluun ja tukemiseen. Artikkelin lopuksi nostamme sosiaalija terveydenhuollon ohjauksen ja neuvonnan keskeiseksi keinoksi tukea muistisairaan ihmisen ja hänen omaisensa mielen hyvinvointia käytännössä. Haluamme painottaa, että mielen hyvinvoinnin edellytysten turvaamisessa ei ole pelkästään kysymys yksittäisistä sosiaali- ja terveydenhuollon tukimuodoista, vaan myös toimintatavasta, jolla kaikkien muistisairaita ihmisiä kohtaavien tulisi toimia. Tämä edellyttää ammattihenkilöstöltä laajaa osaamista, vahvaa eettistä toimintaa ja ymmärrystä siitä, mitkä asiat mielen hyvinvointiin vaikuttavat.

\section{Mielen hyvinvoinnin lähtökohtia}

Hyvinvointi viittaa yleiskielessä vaurauteen ja hyvään terveydentilaan (Kotimaisten kielten keskus). Terveys, elinolot ja toimeentulo liittyvät hyvinvointiin, ja nämä osatekijät yleensä tukevat toisiaan (Moisio, Karvonen, Simpura \& Heikkilä 2008; Saari 2011). Hyvinvointi on kuitenkin myös yksilöllinen kokemus, johon liittyvät muun muassa arvot ja sosiaaliset suhteet. Sekä yhteiskunnallisena käsitteenä että yksilöllisenä kokemuksena hyvinvoinnille on olemassa erilaisia määritelmiä ja mittareita. Sitä voidaan tarkastella esimerkiksi koetun elämänlaadun, osallisuuden ja elinolojen näkökulmista (ks. Murto ym. 2017).

Yksilön hyvinvointia voidaan tarkastella myös mielen hyvinvoinnin näkökulmasta. Mielen hyvinvointi on perusta yksilön kokonaishyvinvoinnille. On sanottu, että ei ole terveyttä ilman mielenterveyttä (WHO 2005). Yleisesti mielen hyvinvoinnin määrittelyssä käytetään siis peilipintana mielenterveyskäsitettä. Mielenterveys on hyvinvoinnin kokemus, johon liittyy omien kykyjen tunnistaminen, tavanomaisista elämänhaasteista selviytyminen ja se, että voi ottaa osaa yhteisönsä toimintaan (WHO 2013). Kysymyksessä on siten myönteinen hyvinvoinnin tunne, yksilöllinen hyvinvoinnin kokemus, kyky nauttia elämästä ja vastata kohdattuihin haasteisiin. Mielen hyvinvointiin vaikuttavat aina myös yhteiskunnalliset tekijät, ympäristö ja sosiaaliset suhteet.

Myös haasteellisissa elämäntilanteissa tai sairauden kohdatessa on mahdollista kokea 
mielen hyvinvointia. Tällöin huomio kiinnittyy resilienssiin, elämänhaasteissa selviytymisen prosessiin, jossa oleellista on, miten ihminen kohtaa vaikeudet ja selviytyy niistä, miten hän asennoituu tilanteeseen ja millaista tukea hänellä on saatavilla (Joutsenniemi \& Lipponen 2015).

Muistisairautta sairastavien ihmisten mielen hyvinvointiin vaikuttavia tekijöitä voidaan peilata heidän kokemustensa kautta sekä haavoittuvuuden näkökulmasta (Heimonen 2010). Kokemuksia kartoittavat tutkimukset valottavat mielen hyvinvointiin vaikuttavien tekijöiden moninaisuutta, mielen ja sosiaalisten suhteiden haavoittuvuutta, sopeutumisen haasteita, yksilöllisiä selviytymiskeinoja, arjen rakentumista sekä tuen tarpeita (Heimonen 2005; Virkola 2014).

Muistisairaan ihmisen mielen hyvinvointia, hyvää elämää ja hyvinvoinnin perustaa voidaan tarkastella myös positiivisen psykologian näkökulmasta (Clarke \& Wolverson 2016). Positiivisessa psykologiassa keskeisiä hyvän elämän ja hyvinvoinnin osatekijöitä ovat myönteiset tunteet, tekemiseen sitoutuminen, ihmissuhteet sekä merkityksellisyyden ja aikaansaamisen kokemus (Seligman 2011).

Positiivinen psykologia tuo mielen hyvinvoinnin tarkasteluun psykologisten perustarpeiden kehikon eli omaehtoisuuden, kyvykkyyden ja yhteenkuuluvuuden näkökulmat (Ryan \& Deci 2000; Martela 2014). Omaebtoisuus tarkoittaa kokemusta siitä, että ihminen on vapaa päättämään omista tekemisistään. Tämä merkitsee valinnan- ja toiminnanvapautta. Kyoykkyys tarkoittaa henkilön kokemusta siitä, että hän osaa, selviää haasteista ja saa asioita aikaan. Tämä merkitsee kykyjen ja taitojen tasoa sekä mahdollisuutta käyttää niitä. Yhteenkuuluvuus puolestaan merkitsee ihmisen tarvetta olla yhteydessä toisiin ihmisiin. Tähän liittyy turvallisuuden kokemus, hyväksytyksi ja arvostetuksi tulemisen tunne sekä kohtaamisen taso.

Jos edellä kuvattuja perustarpeita tarkastellaan muistisairaan ihmisen näkökulmasta, kes- keisiä kysymyksiä ovat, miten muistisairauden etenemisen myötä heikentyvät fyysiset, psyykkiset, sosiaaliset ja kognitiiviset kyvyt vaikuttavat omaehtoisuuden toteutumiseen, mitä kykyjen heikentyminen ja menettäminen merkitsevät kyvykkyyden kokemuksen kannalta ja mistä yhteenkuuluvuuden tunne syntyy. Laveasti tulkiten ja edellisiin kysymyksiin liittyen mielen hyvinvoinnin edellytysten voidaan katsoa kiinnittyvän muistisairautta sairastavan ihmisen autonomiaan, toimijuuteen ja osallisuuteen.

Autonomia tarkoittaa jokaisen toimintakykyisen yksilön yhdenvertaista oikeutta tehdä päätöksiä itseään koskevista asioista (Pietarinen 1993). Autonomian elementtejä ovat kyvykkyys, oikeus saada tietoa, mahdollisuus tehdä päätöksiä ja voimavaroja toteuttaa ne (Topo 2012). Autonomia on yksi keskeisistä muistisairaan ihmisen oikeusturvaa koskevista periaatteista. (Ks. esim. Dworkin 1993; Jaworska 1998; McGee 2014). Sen toteutumisessa yksilön ihmissuhteet - relaatiot - ovat usein keskeisessä asemassa, niin hyvässä kuin pahassa. Toisaalta yksilö voi saada läheisiltään tukea päätöksenteossa, mutta toisaalta on tunnustettava se tosiasia, että kaikissa tilanteissa yksilön tukemisen motiivina ei välttämättä ole hänen etujensa mukainen toiminta. (Herring 2009; Harding 2012 ja 2017; Mäki-PetäjäLeinonen 2017.)

Toimijuus tuo ihmisen esiin reflektoivana, omaa elämäänsä rakentavana ja sitä tarkastelevana yksilönä. Toimijuudella on monia merkityksiä ikääntymiseen ja elämänkulkuun keskittyvässä tutkimuksessa (Marshall 2005; Jyrkämä 2013). Virkolan (2014) mukaan muistisairauden eteneminen muuttaa ihmisen toimijuuden dynamiikkaa. Muistisairaan ihmisen näkökulmasta on tärkeää, että muut tunnistavat hänen toimijuutensa. Osallisuus tarkoittaa niin yhteenkuulumisen ja osallisuuden tunnetta kuin mahdollisuutta toimia ja vaikuttaa omassa asiassaan, yhteisössä ja yhteiskunnassa (ks. esim. Barnes 2005; STM 2013). Osallisuus liittyy myös tunteeseen siitä, että on arvostettu ja tasavertainen yhteisön jäsen. Osallisuuden 
kokemus on edelleen tärkeää myös yksilön hoivasuhteessa, joka tapahtuu niin ikään aina relaationaalisessa kontekstissa (Gastmans 2013).

Edellä esiteltyjä hyvinvoinnin edellytyksiä on aiemmin tarkasteltu lähinnä hoidon ja palveluiden eettisenä perustana, mutta tämän artikkelin keskeisenä kysymyksenä on, mitä ne tarkoittavat mielen hyvinvoinnin edellytyksinä oikeudellisesta näkökulmasta.

\section{Oikeudesta mielen hyvinvoinnin edellytysten turvaamiseen}

\section{Hyvinvointioikeus oikeusalueena}

Kun hyvinvointia tarkastellaan oikeudellisesta näkökulmasta käsin, kysymys on hyvinvointikysymyksiin suuntautuvasta oikeustieteellisestä tutkimuksesta. Hyvinvointioikeus käsitteenä on saanut viime aikoina jalansijaa suomalaisessa yliopistotason opetuksessa ja tutkimuksessa. Hyvinvointioikeudellinen tutkimus on ItäSuomen yliopiston oikeustieteiden tiedekunnan yhtenä painopistealueena, ja ensimmäiset valtakunnalliset hyvinvointioikeuden päivät järjestettiin Joensuussa toukokuussa 2017.

Mistä hyvinvointioikeudessa sitten on kysymys? Terminä "hyvinvointioikeus" ei kuvaa itsenäistä oikeudenalaa vaan oikeustieteellisen tutkimuksen kokonaisuutta, jonka kohteena on taloudelliseen toimeentuloon, sosiaaliseen hyvinvointiin sekä fyysiseen ja psyykkiseen terveyteen liittyvä oikeudellinen sääntely. Hyvinvointioikeuden voidaan katsoa kattavan muun ohella sellaiset vakiintuneet tai vakiintumassa olevat oikeudenalat kuten sosiaalioikeus, terveysoikeus, lääkintä- ja bio-oikeus, lapsioikeus, vanhuusoikeus ja koulutusoikeus. Myös työoikeudella, perheoikeudella ja vero-oikeudella on selvät kytkökset hyvinvointioikeuteen. (UEF oikeustieteet 2017.)

Hyvinvointioikeuden tutkimuksellisessa keskiössä ovat usein yksilön oikeudet, mutta yhtä hyvin tarkastelu voidaan kohdistaa niin toimeentuloturva- ja hyvinvointipalvelujärjes- telmään kuin viranomaisiin ja muihin toimijoihin (ks. esim. Uoti 2003). Kun hyvinvointioikeudellisia kysymyksiä tarkastellaan sosiaali- ja terveydenhuollon säännöskokonaisuuden näkökulmasta, voidaan todeta, että kysymys on säännöistä, jotka koskevat niin hyvinvointipalvelujen järjestämisvastuuta kuin yksilön oikeutta saada hyvinvointiaan tukevia palveluita. Nämä palvelut koskevat usein yksilön fyysiseen hyvinvointiin liittyviä palveluita, mutta yhtä hyvin kysymys voi olla palveluista, jotka liittyvät keskeisesti yksilön mielen hyvinvoinnin tukemiseen. Edelleen on huomattava, että yksilön fyysinen hyvinvointi ja mielen hyvinvointi linkittyvät läheisesti yhteen. Palvelu, joka konkreettisesti liittyy lähinnä fyysisen hyvinvoinnin edistämiseen, voi vaikuttaa laaja-alaisesti myös yksilön mielen hyvinvointiin (WHO 2014). Tästä voi olla kysymys esimerkiksi tilanteessa, jossa ikäihminen saa lääkinnälliseen kuntoutukseen kuuluvaa fysioterapiaa tai apuvälinepalveluita niiden vaikuttaessa hänen mahdollisuuteensa toimia yhteiskunnan täysivaltaisena jäsenenä (toimijuus) ja parantaessa hänen osallisuutensa kokemusta (osallisuus). Edellisessä jaksossa kuvatun mukaisesti nämä hyvinvoinnin elementit liittyvät keskeisesti juuri yksilön mielen hyvinvointiin.

Kun hyvinvointioikeudellisia kysymyksiä tarkastellaan yksilötasolla, niiden voidaan todeta varsin usein koskettavan sellaisten yksilöiden hyvinvoinnin turvaamista, jotka jollakin tavalla ovat avun ja tuen tarpeessa. Tämä tuen tarve voi liittyä lapsuuteen, vanhuuteen, vammaisuuteen, sairauteen, köyhyyteen tai muuhun haavoittuvuutta (ks. Sarvimäki \& Stenbock-Hult 2010) aiheuttavaan syyhyn. Kysymys voi olla ihmisten tukemisesta haavoittavassa tilanteessa, mutta kysymys voi olla myös terveyden ja hyvinvoinnin edistämisestä, joilla pyritään välttämään yksilön joutuminen haavoittuvaan asemaan.

Esimerkiksi muistisairautta sairastavat ihmiset ovat erityisen haavoittuvia (Mackenzie, Rogers \& Dodds 2014). Haavoittuvuus, ihmisarvo ja eettisyys ovat kiinteässä yhteydessä 
toisiinsa (Sarvimäki \& Stenbock-Hult 2010). Hoidon etiikassa on kysymys pohjimmiltaan haavoittuvuuden kohtaamisesta ja haavoittuvan ihmisen ihmisarvon ylläpitämisestä, suojaamisesta ja vahvistamisesta (Gastmans 2013). Muistisairas ihminen kokee kehon, mielen ja ihmissuhteiden haavoittuvuutta. Tällöin on vaarana, että hänen oikeutensa eivät toteudu eikä häntä kohdella ihmisarvoisella tavalla (Sarvimäki \& Stenbock-Hult 2010). Käytännössä tämä näkyy siten, että muistisairaita ihmisiä toiseutetaan herkästi arjen hoivan käytännöissä (Pietilä ym. 2010). Toiseuttaminen on merkittävä uhka tasavertaiselle kansalaisuudelle.

Kaiken kaikkiaan voidaan todeta, että hyvinvointioikeudessa on kysymys laajasta säännöskokonaisuudesta, jolla pyritään turvaamaan yksilön fyysisen, psyykkisen ja sosiaalisen toimintakyvyn ja hyvinvoinnin sekä taloudellisen toimeentulon toteutuminen. Hyvinvoinnin toteutumisessa yksilötasolla puolestaan on kysymys kokonaisvaltaisesta ja moniulotteisesta käsitteestä, jossa keskeistä on yksilön subjektiivinen kokemus oman hyvinvointinsa - kuten autonomiansa, osallisuutensa ja toimijuutensa - toteutumisesta. (Hyvinvoinnin filosofiasta ks. esim. Lagerspetz 2011.) Voidaan siten todeta, että hyvinvointioikeudellinen tutkimus ei tarkastele yksinomaan lainsäädännöllä turvattua resurssipohjaista hyvinvoinnin toteutumista, vaan kysymys voi olla myös koetun hyvinvoinnin tutkimisesta. Tällöin tutkimusmenetelmänä voidaan käyttää niin kutsutusta perinteisestä lainopillisesta tutkimuksesta poikkeavia, esimerkiksi kvalitatiivisia tutkimusmenetelmiä (ks. esim. Harding 2014; Mustasaari \& A1-Sharmani 2018, arvioitavana).

\section{Mielen hyvinvoinnin edellytykset sosiaali- ja terveydenhuollon lainsäädännön valossa}

Muistisairaan ihmisen mielen hyvinvointi on, kuten edellä on kuvattu, yksilöllinen kokemus, johon monet, myös yksilön ulkopuoliset, tekijät vaikuttavat. Tässä artikkelissa autono- mian, osallisuuden ja toimijuuden on todettu olevan mielen hyvinvoinnin keskeisiä edellytyksiä. Yksilöllisenä kokemuksena mielen hyvinvointia ei sinänsä voi puristaa oikeudellisen tarkastelun kehikkoon, mutta siihen vaikuttavina tekijöinä autonomiaa, toimijuutta ja osallisuutta voidaan tarkastella oikeudellisesta näkökulmasta käsin.

Aiempaan määrittelyyn viitaten voidaan todeta, että mielen hyvinvoinnin edellytyksiin ja niiden turvaamiseen liittyvä lainsäädäntö on lopulta varsin laaja. Tarkastelun kohteeksi voisi tulla esimerkiksi yksilön hyvinvointiin keskeisesti liittyvä perustuslain $(731 / 1999$, PL) 19 §:n säännös oikeudesta sosiaaliturvaan. Tuon säännöksen mukaan jokaisella, joka ei kykene hankkimaan ihmisarvoisen elämän edellyttämää turvaa, on oikeus välttämättömään toimeentuloon ja huolenpitoon. Edelleen säännöksen mukaan julkisen vallan on turvattava, sen mukaan kuin lailla tarkemmin säädetään, jokaiselle riittävät sosiaali- ja terveyspalvelut ja edistettävä väestön terveyttä. Niin ikään tarkastelun kohteeksi voisi valikoitua lähes mikä tahansa sosiaalihuoltolain (1301/2014, SHL), sosiaalihuollon asiakaslain (812/2000, AsiakasL) taikka terveydenhuoltolain $(1326 / 2010$, THL) tai potilaslain (785/1992, PotilasL) säännös.

Aihetta voitaisiin edelleen lähestyä tarkastelemalla kansainvälisiä asiakirjoja. Esimerkiksi Euroopan neuvoston suositus ikäihmisten ihmisoikeuksien edistämiseksi (Recommendation CM/Rec(2014)2) on niin kutsuttu soft-law -tason asiakirja, jolla ei ole sitovaa vaikutusta mutta jolla pyritään kannustamaan valtioita ottamaan suositus huomioon lakeja säädettäessä (Rosas 2011). Suosituksen keskeisenä tavoitteena on varmistaa, että ikäihmiset voisivat täysimääräisesti nauttia Euroopan ihmisoikeussopimuksen takaamista ihmisoikeuksista ja yksilön vapausoikeuksista. Suosituksessa korostetaan ikäihmisen oikeutta nauttia oikeuksistaan täysivaltaisesti, ilman syrjintää. Suosituksen mukaan ikäihmisillä on oikeus elää elämäänsä itsenäisesti, itsemääräävästi ja autonomisesti. Tämä sisältää oikeuden 
tehdä itsenäisiä päätöksiä kaikista heitä koskevista asioista mukaan lukien omaisuuteen, tuloihin ja taloudellisiin asioihin, asuinpaikkaan sekä terveyteen liittyvistä kysymyksistä. Kaikkien mahdollisten tätä oikeutta koskevien rajoitustoimien tulee olla suhteellisia liittyen tapauksen olosuhteisiin ja ne edellyttävät sitä, että riittävä suojelu hyväksikäyttöä ja syrjintää vastaan varmistetaan.

\section{Vanhuspalvelulaki tarkastelun keskiössä}

Pyrittäessä tarkastelemaan lähemmin muistisairaan ihmisen oikeutta mielen hyvinvoinnin edellytyksiin, on mielenkiintoista suunnata tarkastelu vuonna 2013 voimaan tulleeseen ikääntyneen väestön toimintakyvyn tukemista sekä iäkkäiden sosiaali- ja terveyspalveluita koskevaan lakiin eli niin kutsuttuun vanhuspalvelulakiin (980/2012, vanhuspalvelulaki, VanhusL). Kyseisessä laissa iäkkäällä henkilöllä tarkoitetaan henkilöä, jonka fyysinen, kognitiivinen, psyykkinen tai sosiaalinen toimintakyky on heikentynyt korkean iän myötä alkaneiden, lisääntyneiden tai pahentuneiden sairauksien tai vammojen vuoksi taikka korkeaan ikään liittyvän rappeutumisen johdosta (VanhusL 3 $\S)$. Suuri osa lain soveltamisalaan kuuluvista iäkkäistä henkilöistä on muistisairauteen sairastuneita. Tässä luvussa tarkastelun kohteena on se, miten vanhuspalvelulaissa on mahdollisesti huomioitu ikäihmisen mielen hyvinvointiin liittyvät kysymykset.

\section{Lain tavoitteet ja keskeiset periaatteet}

Vastausta siihen, miten vanhuspalvelulaki huomioi ikäihmisen mielen hyvinvoinnin kysymyksiä, voidaan lähteä selvittämään vanhuspalvelulain tavoitteista ja keskeisistä periaatteista käsin. Vanhuspalvelulain tarkoituksena on tukea ikääntyneen väestön hyvinvointia, terveyttä, toimintakykyä ja itsenäistä suoriutumista (VanhusL 1 §). Laissa säädetään byvinvointia edistävästä toiminnasta (VanhusL 12 §). Sen mukaan kunnan on järjestettävä ikääntyneen väestön hyvinvointia, terveyttä, toiminta- kykyä ja itsenäistä suoriutumista tukevia neuvontapalveluja. Kunnan on lisäksi tarjottava hyvinvointia, terveyttä, toimintakykyä ja itsenäistä suoriutumista tukevia terveystarkastuksia, vastaanottoja tai kotikäyntejä erityisesti niille ikääntyneeseen väestöön kuuluville, joiden elinoloihin tai elämäntilanteeseen arvioidaan liittyvän palveluntarvetta lisääviä riskitekijöitä. Lakia koskevan hallituksen esityksen mukaan tällaisia riskiryhmiä ovat muiden ohella ikääntyneet omaishoitajat, äskettäin puolisonsa tai muun läheisensä menettäneet, yksinäiset, sairaalasta kotiutuneet sekä muistisairaat ihmiset (HE 160/2012). Edellä mainittuihin hyvinvointia edistäviin palveluihin on sisällytettävä ikääntyneen väestön terveyden ja toimintakyvyn heikkenemisestä aiheutuvien sosiaalisten ja terveydellisten ongelmien tunnistaminen ja niihin liittyvä varhainen tuki (VanhusL 12 § 3 mom).

Vanhuspalvelulakia voidaan tarkastella mielen hyvinvoinnin näkökulmasta myös sen keskeisten periaatteiden valossa. Laissa säädetään palveluntarpeisiin vastaamista ohjaavista yleisistä periaatteista (VanhusL 13 §). Sen mukaan kunnan on järjestettävä iäkkäälle henkilölle laadukkaita sosiaali- ja terveyspalveluja, jotka ovat hänen tarpeisiinsa nähden oikea-aikaisia ja riittäviä. Palvelut on toteutettava niin, että ne tukevat iäkkään henkilön hyvinvointia, terveyttä, toimintakykyä, itsenäistä suoriutumista ja osallisuutta. Muun palveluntarpeen ennalta ehkäisemiseksi on kiinnitettävä huomiota erityisesti kuntoutumista edistäviin ja kotiin annettaviin palveluihin. Palvelujen laadusta säädetään lain 4 luvussa, ja sen perusedellytyksiä ovat toimintayksikön riittävä henkilöstö (20 §), osaava johtaminen $(21 \S)$ ja asianmukaiset toimitilat (22 §). Lakia koskevan hallituksen esityksen mukaan palvelujen laadukkuuden lisäksi asiakkaan kokeman laadun kannalta on tärkeää, että hän saa osakseen kunnioittavaa ja yksilöllistä kohtelua ja että hänen toivomuksillaan on vaikutusta hänelle järjestettävien palvelujen toteuttamiseen. Tämän osalta viitataan myös potilaslakiin ja sosiaalihuollon asiakaslakiin, joissa 
niin ikään säädetään potilaan ja asiakkaan oikeudesta laadukkaisiin palveluihin ja hyvään kohteluun. (HE 160/2012.)

Edelleen vanhuspalvelulaissa säädettyjen pitkäaikaisen hoidon ja huolenpidon toteuttamista ohjaavien periaatteiden mukaan pitkäaikaista hoitoa ja huolenpitoa turvaavat sosiaali- ja terveyspalvelut on toteutettava niin, että iäkäs henkilö voi "kokea elämänsä turvalliseksi, merkitykselliseksi ja arvokkaaksi ja että hän voi ylläpitää sosiaalista vuorovaikutusta sekä osallistua mielekkääseen, hyvinvointia, terveyttä ja toimintakykyä edistävään ja ylläpitävään toimintaan” (VanhusL 14.2 §).

Edellä mainitun säännöksen määrittämä kokemuksellisuus on keskeinen asia, jolla hyvin toteutuessaan on mielen hyvinvointia edistävä vaikutus. Voidaan nimittäin olettaa, että kokemus elämän turvallisuudesta, merkityksellisyydestä ja arvokkuudesta heijastuu mielen hyvinvointiin. Lakia koskevan hallituksen esityksen mukaan iäkkään henkilön merkitykselliseen ja arvokkaaseen elämään kuuluu, että häntä kohdellaan kunnioittaen hänen aikuisuuttaan, yksilöllisyyttään ja intimiteettiään. Arvokas elämä edellyttää muun ohella, että iäkästä henkilöä tuetaan suoriutumaan päivittäisistä toimista, kuten henkilökohtaisen hygienian hoitamisesta, pukeutumisesta ja ruokailusta. Edelleen lakia koskevan hallituksen esityksen mukaan säännöksessä mainitut periaatteet tulee ottaa huomion toimintayksikön omavalvonnassa, ja niiden toteutumista voidaan arvioida asiakkailta ja henkilöstöltä kerättävän palautteen avulla. (HE 160/2012; ks. myös Perttola 2017).

Arvokkaan elämän turvaamisen periaate kiinnittyy asiakaslähtöisyyteen ja ammattihenkilöstön toiminnan etiikkaan. Arvokkaan elämän turvaamista pidettiin myös alkuperäisessä vanhuspalvelulaissa yhtenä pitkäaikaiseen laitoshoitoon pääsemisen perusteena. Sittemmin vuonna 2015 voimaan saatetussa lakimuutoksessa tästä perusteesta kuitenkin luovuttiin. Uuden säännöksen mukaan laitoshoitoon on oikeus vain, jos siihen on lääketieteelliset tai asiakas- tai potilasturvallisuuteen liittyvät pe- rusteet (VanhusL 14a §). On aiheellista kysyä, näkyykö tämän perusteen poistaminen mahdollisesti hoivan ja palvelujen käytännöissä. Tiedotusvälineissä on jopa esitetty väitteitä, joiden mukaan vanhukset ovat ajoittain heitteillä omassa kodissaan.

\section{Vanhuspalvelulaki kokonaisuutena}

Vanhuspalvelulakia kokonaisuutena tarkastelemalla voidaan ylipäätään todeta, että kysymys on säännöksistä, jotka hyvin toteutuessaan voivat vaikuttaa ikäihmisen mielen hyvinvointiin. Mistään konkreettisista palveluista vanhuspalvelulaissa ei kuitenkaan säädetä, vaan se on pikemminkin prosessikuvaus palveluketjusta, jota noudattamalla ikäihmisen oikeuksien tulisi toteutua. Laki tukeutuu siten hyvin keskeisesti periaatetason normeihin ja ohjeistukseen siitä, millä tavoin ikääntyneillä ihmisillä on oikeus tulla kohdelluksi. Kysymyksessä on menettelyja laadunvarmistuslaki (Arajärvi 2014), ja tämän kaltaista kuvausta on myös useissa kansainvälisissä soft-law -tason asiakirjoissa, kuten edellä mainitussa Euroopan neuvoston suosituksessa ikäihmisten ihmisoikeuksien edistämiseksi (Recommendation CM/Rec(2014)2).

On sinänsä tavoiteltavaa, että lailla väli1lisesti vaikutetaan yksilön mielen hyvinvoinnin edistämiseen. On tärkeää, että ikäihmisen hoivaa ja palvelua lähestytään yksilökeskeisesti ja kokonaisvaltaisesti ja että hänellä on oikeus tulla tuossa prosessissa kohdelluksi siten, että hänen aikuisuuttaan ja yksilöllisyyttään kunnioitetaan. Tästä huolimatta voidaan perustellusti kysyä, mikä on tämän kaltaisten periaateluontoisten säännösten merkitys, joiden tavoitteena on lähinnä vaikuttaa hoivakäytäntöihin ja asiakkaan kohtaamiseen. Tämä on keskeinen kysymys, sillä vaarana voi olla, että sääntelyn konkreettinen merkitys käytännön tasolla jää vähäiseksi (Hoppania, Mäki-Petäjä-Leinonen \& Nikumaa 2017). Tällaisenaan vanhuspalvelulaki sisältää sinänsä vahvat periaatteet, mutta niiden tueksi ei juuri löydy kyseisiä periaatteita tukevia, vahvoja sääntöjä. Niinpä esimerkiksi vanhuspalvelujen tilaa kuvaavassa selvityksessä 
on todettu, että terveyttä ja hyvinvointia edistävien palveluiden kohdentamisessa, esimerkiksi kotona asuville muistisairaille, on parannettavaa (THL 2016).

Vanhuspalvelulaki onkin saanut kritiikkiä osakseen muun ohella siitä, että se on kuvaus ikäihmisen hoiva-ja palveluketjusta sisältämättä konkreettisia säännöksiä vanhushoivasta. Säännökset ovat periaateluonteisia ja retoriikka siitä, että ikäihminen saisi palvelunsa vanhuspalvelulain nojalla, voi johtaa harhaan; palvelut saadaan pääsääntöisesti sosiaalihuoltolain nojalla. (Hoppania ym. 2017.) Edelleen lakia on kritisoitu siitä, että se ei sisällä subjektiivista oikeutta palvelujen saamiseen, säännöksiä henkilöstömitoituksesta tai sanktioita lain tavoitteiden vastaisesta toiminnasta (Hoppania 2015). Lisäksi laki ei sisällä juurikaan sellaista, mistä ei olisi säännöksiä muussa lainsäädännössä, esimerkiksi keväällä 2015 uudistetussa sosiaalihuoltolaissa. Niinpä sosiaalihuoltolaki sisältää säännökset esimerkiksi oikeudesta saada määrätyt palvelut kolmessa kuukaudessa sekä puolisoiden lähtökohtaisesta oikeudesta asua yhdessä. Näistä samoista asioista säädetään myös vanhuspalvelulaissa (ks. Hoppania ym. 2017). Arajärven (2014) mukaan lain voisikin tulkita olevan tarpeeton ja osa niin kutsuttua normitulvaa.

\section{Mielen hyvinvointia tukevien säännösten rakenne lainsäädännössä}

Oikeusnormit voidaan jakaa oikeussääntöihin ja oikeusperiaatteisiin. Oikeussäännöille on ominaista, että niitä on noudatettava kaikissa niiden soveltamisalaan kuuluvissa tilanteissa. Sen sijaan oikeusperiaate, esimerkiksi itsemääräämisoikeuden periaate, saattaa väistyä ratkaisua toiseen suuntaan ohjaavan periaatteen, esimerkiksi suojaamisen periaatteen, tieltä. Oikeusperiaatteet eivät ole tässä mielessä yhtä velvoittavia kuin oikeussäännöt, ja niillä voi olla hieman erilainen tehtävä toisaalta normina ja toisaalta tulkintaohjeena. Periaatetta voidaan siten käyttää paitsi itsenäisenä nor- mina myös tulkintaa ohjaavana normina, jolloin sitä käytetään apuna tulkittaessa jotain laissa olevaa oikeussäännöstä. Toisaalta myös jokin lainsäännös voi olla periaatteen kaltainen, jos se on kirjoitettu avoimeksi. Säännöstä käytetään tällöin muodollisesti säännön mutta sisällöllisesti periaatteen tavoin. (Ks. esim. Tuori \& Kotkas 2016).

Vanhuspalvelulakia ja muutakin sosiaalija terveydenhuollon lainsäädäntöä tarkastelemalla voidaan todeta, että mielen hyvinvoinnin edellytysten turvaamisen näkökulmasta lainsäädännöstämme on löydettävissä ainakin kolmen tasoisia normeja. Ensinnäkin on edellä mainittuja periaatetason normeja, jotka liittyvät hyvin vahvasti yksilön kohteluun ja kohtaamiseen. Kun kysymys on esimerkiksi muistisairaan ihmisen kohtaamisesta, sovellettavana oleva säännös on periaateluontoinen silloin, kun kysymys on esimerkiksi itsenäisen suoriutumisen tai hyvinvoinnin tukemisesta. Näistä säädetään vanhuspalvelulain 13 ja 14 §:ssä, ja ne velvoittavat myös sosiaali- ja terveydenhuollon ammattihenkilöitä.

Periaateluontoisten sääntöjen lisäksi laissa säädetään menettelyllisistä oikeuksista, joita käyttämällä esimerkiksi sosiaalihuollon asiakas voi saada tarvitsemansa palvelut. Näitä ovat muun ohella sosiaalihuoltolaissa ja vanhuspalvelulaissa säädetyt ohjaus ja neuvonta, palvelutarpeiden selvittäminen, palvelu- tai asiakassuunnitelma sekä päätös sosiaalipalvelujen myöntämisestä. Oikeustieteessä näiden menettelyllisten oikeuksien ajatellaan tukevan materiaalisten oikeuksien kuten esimerkiksi sosiaalihuoltolaissa säädetyn kotipalvelun (19 §), sosiaalisen kuntoutuksen (17 §) tai liikkumista tukevien palvelujen $(23 \S)$ toteutumista (Arajärvi 2014). Myös näillä menettelyllisillä oikeuksilla sekä materiaalisilla palveluilla voi hyvin toteutuessaan olla konkreettista vaikutusta yksilön mielen hyvinvointiin ja sitä kautta mahdollisuuteen elää yhteiskunnan täysivaltaisena jäsenenä sekä kokea osallisuutta ja toimijuutta. Voidaan siten todeta, että esimerkiksi laadukkaalla ohjauksella ja neuvonnalla voi menet- 
telyllisenä oikeutena olla myös materiaalinen ulottuvuus mielen hyvinvoinnin näkökulmasta. Seuraavassa jaksossa tarkastelemme konkreettisesti, mitä on laadukas ohjaus ja neuvonta muistisairaan ihmisen näkökulmasta ja miten sillä voidaan tukea mielen hyvinvointia.

\section{Muistisairaan ihmisen mielen hyvinvoinnin edellytysten tukeminen käytännössä: esimerkkinä laadukas ohjaus ja neuvonta}

Tuki on tärkeää haasteellisessa elämäntilanteessa

Muistisairas ihminen kohtaa sairauden edetessä monia mielen hyvinvointiin vaikuttavia haasteita. Sairauden etenevä luonne, fyysisten, psyykkisten, sosiaalisten ja kognitiivisten kykyjen heikentyminen, arjessa selviytymisen haasteet, muutokset sosiaalisissa suhteissa sekä tulevaisuuteen liittyvät huolet heijastuvat väistämättä mielen hyvinvointiin. Kysymys on muistisairauteen liittyvästä haavoittuvuudesta (Dröes, van Mierlo, van der Roest \& Meiland 2010). Ihmisten elämäntilanteissa ja selviytymiskeinoissa on yksilöllisiä eroja, minkä vuoksi mielen hyvinvoinnin edellytystenkin toteutumista tulisi tarkastella kokonaisvaltaisesti ja aina yksilön tilannetta ja kokemuksia tavoittaen.

Selviytyäkseen sairauden mukanaan tuomista haasteista muistisairautta sairastava ihminen tarvitsee hyvinvointia ja toimintakykyä ylläpitävää, yksilöllistä ja räätälöityä tukea koko sairausprosessin ajan. Ohjaus ja neuvonta kuuluvat olennaisena osana palvelu- ja hoitoketjun kaikkiin vaiheisiin, ja ne liittyvät keskeisesti muistisairaan ihmisen yksilöllisen hoito-, kuntoutus- ja palvelusuunnitelman laatimiseen ja kotona selviytymisen tukemiseen (Käypä hoito 2017; ks. myös KalliomaaPuha 2014). Tukemiseen kuuluvat sairastuneen ihmisen ja hänen läheisensä tiedollinen tuki sekä sosiaalista hyvinvointia edistävä ja kotona asumista turvaava tuki (HuhtamäkiKuoppala ym. 2015). Sosiaalisella tuella on todettu olevan vaikutusta yksilön mielen hyvinvoinnille ja osallisuuden kokemukselle (ks. esim. Turner 1981; Abbey, Abramis \& Caplan 1985; Forsman, Nordmyr \& Wahlbeck 2011; Pynnönen, Törmäkangas, Rantanen, Tiikkainen \& Kallinen 2018). Iäkkäiden ihmisten mielen hyvinvoinnin vahvistamisessa on otettava huomioon yksilön toiveisiin ja tarpeisiin sekä mielenkiinnon kohteisiin räätälöidyt merkitykselliset sosiaaliset aktiviteetit. (Forsman ym. 2011.)

\section{Oikeus ohjaukseen ja neuvontaan}

Yksilön ohjauksessa ja neuvonnassa on kysymys lakisääteisestä oikeudesta saada ohjauksen ja neuvonnan palveluja. Lain tasolla ohjauksesta ja neuvonnasta säädetään esimerkiksi hallintolaissa (434/2003, 8 §), sosiaalihuollon asiakaslaissa (5 §), sosiaalihuoltolaissa $(6 \S)$ ja vanhuspalvelulaissa (12 §). Kysymyksessä olevat säännökset ovat pakottavaa oikeutta eli kunnalla on velvollisuus ohjaus- ja neuvontapalvelujen järjestämiseen. Vanhuspalvelulain mukaisiin neuvontapalveluihin on sisällytettävä: hyvinvoinnin edistämiseen ja sairauksien ehkäisyyn tähtäävä ohjaus; terveyden heikkenemisestä aiheutuvien sosiaalisten ja terveydellisten ongelmien tunnistaminen ja niihin liittyvä tuki; sosiaalihuoltoa ja muuta sosiaaliturvaa koskeva ohjaus; sairaanhoitoa, monialaista kuntoutusta ja turvallista lääkehoitoa koskeva ohjaus; sekä ohjaus kunnassa tarjolla olevien palvelujen käyttöön (VanhusL 12.3 §). Lakia koskevan hallituksen esityksen mukaan palvelujen toteuttamistavat ovat kuntien harkinnassa, mutta ne olisi tarkoituksenmukaista järjestää lähipalveluina, jotta ne olisivat mahdollisimman helposti ikääntyvien kuntalaisten saatavilla (HE 160/2012).

Riittävällä ja laadukkaalla ohjauksella ja neuvonnalla luodaan myös edellytyksiä osallistua itseä koskevien päätösten tekemiseen. Osallisuus on keskeinen vanhuspalvelulain 
periaate, ja oikeus osallisuuteen on huomioitu esimerkiksi palvelusuunnitelmaa koskevassa vanhuspalvelulain 16 §:ssä. Sen mukaan palvelusuunnitelmassa on määriteltävä iäkkään henkilön toimintakykyä koskevan arvion perusteella, millainen sosiaali- ja terveydenhuollon palvelujen kokonaisuus tarvitaan hänen hyvinvointinsa, terveytensä, toimintakykynsä ja itsenäisen suoriutumisensa tukemiseksi sekä hänen hyvän hoitonsa turvaamiseksi. Iäkkään henkilön ja tarvittaessa hänen omaisensa, läheisensä tai hänelle määrätyn edunvalvojan kanssa on neuvoteltava vaihtoehdoista kokonaisuuden muodostamiseksi. Iäkkään henkilön näkemykset vaihtoehdoista on kirjattava suunnitelmaan. Samankaltaisesti on säädetty myös esimerkiksi potilaslaissa (4a §) ja sosiaalihuollon asiakaslaissa (7 ja 9 §).

Vaikka laissa turvataan oikeus laadukkaaseen ohjaukseen ja neuvontaan, tämä tavoite ei ole aina toteutunut käytännössä. Muistisairaat ja heidän läheisensä ovat kokeneet muun ohella ohjaus- ja neuvontavelvollisuuden välttelemistä ja jatkuvaa eteenpäin ohjaamista - "luukuttamista”. Tämä voi olla seurausta paitsi ammattihenkilöstön puutteellisesta osaamisesta myös niukoista ajallisista resursseista. On syntynyt tilanteita, joissa muistisairas ja hänen läheisensä ovat saaneet epätarkkaa tai jopa virheellistä ohjausta ja neuvontaa tai neuvontaa, joka ei ole ollut tarpeisiin nähden riittävää. (Nikumaa 2012). Vielä huonommassa tilanteessa ovat toisinaan olleet yksin asuvat muistisairaat ihmiset, jotka eivät välttämättä osaa pyytää apua, kysyä eri vaihtoehdoista tai joiden osalta päätökset saatetaan tehdä heidän puolestaan, heitä lainkaan kuulematta (Mäki-PetäjäLeinonen 2010). Palvelujärjestelmän pirstaleisuus ja vaikea hahmotettavuus hankaloittavat tuen ja palvelujen löytämistä (Saarenheimo \& Pietilä 2006).

Ohjauksessa ja neuvonnassa on kysymys monisyisestä kokonaisuudesta, joka hyvin onnistuakseen edellyttää monipuolista osaamista. Muistisairaan ihmisen mielen hyvinvoin- nin tukemisen näkökulmasta laadukkaalla ohjauksella ja neuvonnalla on keskeinen rooli. Seuraavassa tarkastelemme näitä laadukkaan neuvonnan eri elementtejä muistisairaan ihmisen näkökulmasta.

\section{Laadukkaan neuvonnan elementtejä}

Muistityö on jatkuvasti kehittyvä erikoisala (Manthorpe \& Iliffe 2005; Tanner 2011; Manthorpe 2016), jossa sairastuneen ja hänen omaisensa kohtaaminen ja tukeminen on olennaisessa roolissa (Huhtamäki-Kuoppala ym. 2015). Muistisairaita ihmisiä kohtaavien ammattihenkilöiden tulee hallita ohjauksen ja neuvonnan kokonaisuus ja osattava toteuttaa sitä työssään (Eloniemi-Sulkava ym. 2010). Ohjaus- ja neuvontataidot sekä ratkaisukeskeinen lähestymistapa kuuluvat olennaisena osana muistisairaita ihmisiä kohtaavien ammattihenkilöiden osaamiseen.

Laadukas ohjaus ja neuvonta on yksilöllis$t a ̈$, ja sen sisältö voi vaihdella sairauden vaiheesta ja yksilön tilanteesta riippuen (Tanner 2011). Muistioireiden selvittelyyn liittyvä ohjaus, diagnoosin asettamisen jälkeen tarvittava tiedollinen tuki sekä omaisen ohjaus ja neuvonta tukevat sairauden kanssa selviytymistä. Laadukas neuvonta tukee muistisairauteen sairastuneen ihmisen identiteettiä, auttaa selviytymään sairauden kanssa, tukee omannäköistä elämää ja auttaa valmistautumaan tulevaisuuteen (Heimonen \& Mäki-Petäjä-Leinonen 2015).

Muistisairaan ihmisen kokonaistilanteen kartoitus on tärkeä osa yksilöllistä ohjausta ja neuvontaa. Tähän liittyvät nykytilanteen ja elämänhistorian kartoitus sekä tulevaisuuden toiveisiin liittyvien kysymysten selvittäminen (Tanner 2011). Myös yksilön läheisverkoston kartoittaminen on tärkeässä roolissa (Abbey ym. 1985), ja siihen on velvollisuus jo sosiaalihuoltolainkin nojalla (SHL 43 §). Muistisairaan ihmisen tunteminen on hänen mielen hyvinvointinsa vahvistamisen perusta. 
Nykytilanteen ja elämänhistorian tuntemisen kautta valottuvat merkitykselliset asiat ja mielenkiinnon kohteet, toimijuuteen ja toimintakykyisyyteen liittyvät näkökulmat sekä arjen voimavarat. Tulevaisuuden toiveiden kartoittamisessa keskeinen kysymys on, millaista elämää muistisairauteen sairastunut ihminen haluaa elää sairauden edetessä. Tärkeitä selvitettäviä asioita voivat olla asumiseen, hoivaan ja hoitoon liittyvät arjen kysymykset. Olennaista on myös selvittää tulevaisuuteen liittyviä ajatuksia ja huolia ja antaa tietoa huolien hälventämiseksi.

Taito kohdata muistisairas ihminen arvostavasti on myös laadukkaan neuvonnan keskeinen elementti. Kohtaamisen taitoon liittyy muistisairautta sairastavan ihmisen haavoittuvuuden ymmärtäminen sekä asiakkaan autonomian ja ihmisarvon tukeminen. Kysymys on taidosta kuulla muistisairautta sairastavan ihmisen mielipiteitä ja toiveita, tunnistaa hänen tarpeitaan ja arvostaa häntä omaa elämäänsä koskevissa päätöksissä. Kysymys on oikeudesta paitsi tehdä itsenäisiä päätöksiä, myös luoda edellytyksiä osallistua itseä koskevien päätösten tekemiseen. (Heimonen \& Mäki-PetäjäLeinonen 2015; Kalliomaa-Puha 2017.)

Kohtaamisen taidon lisäksi laadukas ohjaus ja neuvonta vaativat monialaista osaamista. Esimerkiksi psykologisen osaamisen hyödyntämiselle on muistisairaan ihmisen ja hänen läheisensä tukemisessa selkeä tarve. Tarvitaan keinoja ja toimintatapoja, joilla voidaan tukea muistisairaita ihmisiä jäsentämään tunteitaan ja ajatuksiaan sekä käsittelemään sairauden aiheuttamia muutoksia ja tulevaisuuteen liittyviä kysymyksiä (Hänninen \& Heimonen 2012). Näin voidaan tunnistaa muistisairaan ihmisen psykososiaalisen tuen tarpeita. Ihmisellä on tarve osallistua, saada arvostusta ja toteuttaa itseään. Jos näihin tarpeisiin vastataan, syntyy kokemus arjen mielekkyydestä ja merkityksellisyydestä. Mahdollisuus saada vertaistukea, keskustella muiden samassa tilanteessa olevien kanssa ja jakaa omia ajatuksiaan ovat osa psy- kososiaalisen tuen kokonaisuutta ja mielen hyvinvointiin heijastuva tekijä.

Laadukas ohjaus ja neuvonta edellyttää myös oikeudellista osaamista, sillä muistisairauteen sairastuneella ja hänen omaisillaan on tarve saada tietoa sairauteen liittyvistä oikeudellisista kysymyksistä (Raivio, Mäki-PetäjäLeinonen, Laakkonen, Tilvis \& Pitkälä 2008). Kysymyksessä voi olla tiedon antaminen esimerkiksi erilaisista sosiaaliturvan tukimuodoista tai ikääntymisen ennakoinnin keinoista kuten esimerkiksi perustietojen antaminen hoitotahdon tekemisestä tai edunvalvontavaltuutuksesta. Ohjausta ja neuvontaa antavalla sosiaali- ja terveydenhuollon ammattihenkilöllä tulisi tämän vuoksi olla riittävät perustiedot myös niistä kysymyksistä,jotka liittyvät muistisairaan ihmisen oikeuksien ja oikeusturvan toteutumiseen. Ammattihenkilöstö tarvitsee tietoa ja koulutusta keinoista, joilla voidaan tukea jäljellä olevaa oikeudellista toimintakykyä sekä mahdollistaa tulevaisuutta koskevien ratkaisujen ja suunnitelmien tekeminen. (MäkiPetäjä-Leinonen 2013). Näin tuetaan sairastuneen autonomiaa ja toimijuutta. Myös eri ammattiryhmien, kuten sosiaalityöntekijöiden ja lakimiesten, välinen yhteistyö voi olla tärkeässä roolissa annettaessa neuvontaa oikeudellisissa kysymyksissä (Werner \& Doron 2016; Duffy, Basu \& Pearson 2012).

Johtopäätöksenä voidaan todeta, että ohjaukseen ja neuvontaan liittyvä eettinen näkökulma kiteytyy siihen, miten ammattihenkilöstö kohtaa muistisairauteen sairastuneen ihmisen. Kysymys on henkilöstön toimintaa ohjaavista ammattieettisistä periaatteista. Ihmisarvoa vahvistava kohtaaminen ja haavoittuvuuden ymmärtäminen on kaiken perusta. Kohtaamisen taidon lisäksi laadukas ohjaus ja neuvonta vaativat monialaista osaamista. Näin ohjauksella ja neuvonnalla voidaan antaa oikea-aikaista tietoa, vahvistaa muistisairauteen sairastuneen ja hänen läheistensä voimaantumista ja tuoda toivon näkökulmaa muuttuneeseen elämäntilanteeseen. Laadukkaassa oh- 
jauksessa ja neuvonnassa eettinen, psykologinen ja oikeudellinen ulottuvuus liittyvät saumattomasti yhteen. Laadukas neuvonta on muistisairaan ihmisen oikeus.

\section{Lopuksi}

Muistisairaan ihmisen mielen hyvinvointiin heijastuvat sosiaaliset suhteet ja se tapa, jolla hän tulee kohdatuksi. Muiden tapa asennoitua muistisairaaseen ihmiseen sisäistyy helposti hänen omiin käsityksiinsä itsestään ja kyvyistään (Langdon, Eagle \& Warner 2007). Kansallisessa muistiohjelmassa korostetaan kannustavien ja rohkaisevien asenteiden merkitystä (STM 2012).

Muistisairauteen sairastuneella ihmisellä on oikeus hyvinvointiin ja hyvään elämään. Hänellä on oikeus tulla kohdatuksi ainutlaatuisena ihmisenä, päättää omaan elämäänsä ja hoitoonsa liittyvistä kysymyksistä sekä toteuttaa itseään ja kokea osallisuutta. Psykologisiin perustarpeisiin pohjaavat omaehtoisuuden, kyvykkyyden ja yhteenkuuluvuuden mahdollisuudet kiinnittyvät arjen toimintaan, ihmissuhteisiin ja kohtaamisiin. Autonomian, toimijuuden ja osallisuuden tukeminen ovat myös tuen, palvelujen ja hoidon eettinen ja oikeudellinen perusta. On otettava huomioon sekä mielen hyvinvoinnin edellytykset että se, miten psyykkistä pahoinvointia aiheuttavat seikat tulevat minimoitua tai poistettua. Ammattihenkilöstöllä on velvollisuus toteuttaa sellaista toimintaa, joka on tämän lähtökohdan mukaista.

Muistisairaan ihmisen arvostava kohtaaminen ja hyvä kohtelu liittyvät sosiaali- ja terveydenhuollon ammattihenkilöstön osaamiseen. Kysymys on ammattieettisestä lähtökohdasta, jolla on vahva oikeudellinen perusta. Lainsäädännössämme on joukko sääntöjä, jotka liittyvät vahvasti yksilön kohteluun ja kohtaamiseen. Ne velvoittavat sosiaali- ja terveydenhuollon ammattihenkilöitä ja ovat hyvin lähellä sosiaali- ja terveydenhuollon ammatti- henkilöiden ammattieettisiä periaatteita, jotka kuvaavat hyvää ja tavoiteltavaa toimintaa. Tällaisten sääntöjen omaksumisella lainsäädäntöön voidaan nähdäksemme katsoa tavoiteltavan keskeisesti juuri yksilön mielen hyvinvoinnin turvaamista.

Olemme tässä artikkelissa tarkastelleet lähemmin vanhuspalvelulakia yksilön mielen hyvinvoinnin turvaamisen näkökulmasta ja todenneet lain tukeutuvan hyvin keskeisesti periaatetason normeihin ja ohjeistukseen siitä, millä tavoin ikääntyneillä ihmisillä on oikeus tulla kohdelluksi. Lainsäädäntö ei siten ainakaan estä mielen hyvinvointia edistävää työotetta vaan päinvastoin velvoittaa siihen. Säännökset, joilla pyritään vaikuttamaan hoivakäytäntöihin ja asiakkaan kohtaamiseen, luovat hyvän pohjan mielen hyvinvointia edistävälle kohtaamiselle ja edellytyksiä autonomian tukemiselle. Kuitenkin viime kädessä kysymys on siitä, millaisia valintoja työntekijät ja heidän työyhteisönsä tekevät.

Paitsi lainsäädäntö, myös ammattieettiset periaatteet ohjaavat ja antavat perustan sosiaali- ja terveydenhuollon ammattihenkilön sekä koko työyhteisön toiminnalle (ks. ETENE 2011). Eettisesti tämä tarkoittaa sitä, että jokainen ammattihenkilö tunnistaa oman toimintansa vaikutukset muistisairautta sairastavan ihmisen mielen hyvinvointiin. Tämä haastaa myös työyhteisön määrittämään yhdessä tavoitteita, toimintaperiaatteita ja keskustelemaan toimintaa ohjaavista arvoista. Kysymys on hyvästä johtamisesta, jossa hyvää kohtelua ja kohtaamista edellytetään kaikilta hoivayhteisössä toimivilta ammattihenkilöiltä.

Muistisairauteen sairastuneen ihmisen mielen hyvinvointi ja sen edellytysten turvaaminen on hoitoa ja palveluja laajempi kysymys. Sen yhteydessä on tarkasteltava, miten muistisairas ihminen voi kokea olevansa tasavertainen kansalainen, elää autonomista elämää ja kokea osallisuutta. Tässä meitä jokaista haastetaan kanssaihmisinä tarkastelemaan omia asenteitamme ja toimintatapojamme. 
Haluamme esittää lämpimät kiitoksemme Gerontologia-lehden refereille sekä professori Toomas Kotkakselle ja dosentti Anneli Sarvimäelle heiltä saamastamme analyyttisesta ja artikkelia edistäneestä palautteesta.

\section{Kirjallisuus}

Abbey A., Abramis, D.J. \& Caplan, R.D. (1985). Effects of different sources of social support and social conflict on emotional well-being. $B a-$ sic and Applied Social Psychology, 6:2, 111-129. doi:10.1207/s15324834basp0602_2

Arajärvi, P. (2014). Vanhuspalvelulaki - Mitä ja miksi? Teoksessa Mäki-Petäjä-Leinonen, A. \& Nieminen, L. (toim.), Vanbuus ja oikeus (s. 257-282). Helsinki: Lakimiesliiton kustannus.

Barnes, M. (2005). The same old process? Older people, participation and deliberation. Aging \& Society 25, 245-259. doi:10.1017/S0144686X04002508

Cattan, M. (toim.) (2009). Mental health and well-being in later life. Maidenhead: Open University Press.

Clarke, C. \& Wolverson, E. (toim.) (2016). Positive psychology approaches to dementia. London: Jessica Kingsley Publishers.

Dröes, R.M., van Mierlo, L.D., van der Roest, H.G. \& Meiland, F.J.M. (2010). Focus and effectiveness of psychosocial interventions for people with dementia in institutional care settings from the perspective of coping with the disease. Non-pharmacological Therapies in Dementia 1(2), 139-161. Haettu 15.6.2017 osoitteesta:

https://www.vumc.nl/afdelingen-themas/ 5177225/6987156/2010droe.pdf.

Duffy, J., Basu, S. \& Pearson, K. (2012). Older people and legal advice - the need for joined up and creative approaches. Journal of Social Welfare $\mathcal{O}^{\circ}$ Family Law, 34(1), 31-47. doi:10.1080/09649069.2012.675463

Dworkin, R. (1993). Life's dominion: an argument about abortion and euthanasia. London: HarperCollins.

Eloniemi-Sulkava, U., Saarenheimo, M., Laakkonen, M-L., Pietilä, M., Savikko, N. \& Pitkälä, K. (toim.) (2006). Omaishoito ybteistyönä. Iäkkäiden dementiaperheiden tukimallin vaikuttavuus. Tutkimusraportti 14. Helsinki: Vanhustyön keskusliitto.

\section{Yhteydenotto:}

Sirkkaliisa Heimonen, PsT, sh, toimialapäällikkö

Ikäinstituutti

Sähköposti: sirkkaliisa.heimonen@ikainstituutti.fi

Eloniemi-Sulkava, U., Rahkonen, T., Erkinjuntti, T., Karhu, K., Pitkälä, K., Pirttilä, T., Vuori, U. \& Suhonen, J. (2010). Moniammatilliset tietotaidot ovat muistisairauksien hyvän hoidon edellytys. Suomen Lääkärilehti 65(39), 3144-3146.

Eloniemi-Sulkava, U \& Savikko, N. (toim.) (2011). MielenMuutos muistisairaiden ibmisten hoidossa. Käytösoireiden hoidosta muistisairaan ihmisen hyvinvoinnin kokonaisvaltaiseen tukemiseen. MielenMuutos tutkimus- ja kehittämishanke, tutkimusraportti 3. Helsinki: Vanhustyön keskusliitto.

ETENE (2011) Sosiaali- ja terveysalan eettinen perusta. ETENE-julkaisuja 32, 2011.

Forsman, A. K., Nordmyr, J. \& Wahlbeck, K. (2011). Psychosocial interventions for the promotion of mental health and the prevention of depression among older adults. Health Promotion International 26(S1), 85-107. doi:10.1093/heapro/dar074.

Gastmans, C. (2013).Dignity-enhancing nursing care: a foundational ethical framework. Nursing Ethics, 20(2),142-149. doi:10.1177/0969733012473772

Haarni, I. (toim.) (2014). Ikääntyvä mieli. Mielen hyvinvointia vanhetessa. Helsinki: Suomen Mielenterveysseura.

Harding, R. (2012). Legal constructions of dementia: discourses of autonomy at the margins of capacity. Journal of Social Welfare E Family Law, 34 (4), 425-442. doi:10.1080/09649069.2012.755031

Harding, R. (2014). Dementia and Carers: Relationality and Informal Carers' Experiences. Teoksessa Foster, C., Herring, J. \& Doron, I. (toim.), The Law and Ethics of Dementia (s. 379-391). Hart Publishing.

Harding, R. (2017). Care and relationality: supported decision making under the UN CRPD. Teoksessa Harding, R., Fletcher, R. \& Beasley, C. (toim.), ReValuating care in theory, law and policy. Cycles and connections (s.114-130). London: Routledge. 
HE 160/2012. Hallituksen esitys Eduskunnalle laiksi ikääntyneen väestön toimintakyvyn tukemisesta sekä iäkkäiden sosiaali- ja terveyspalveluista sekä laiksi terveydenhuoltolain $20 \S: n$ kumoamisesta.

Heimonen, S. (2005). Työikäisenä Alzheimerin tautiin sairastuneiden ja heidän puolisoidensa kokemukset sairauden alkuvaiheessa. Jyväskylä Studies in Education, Psychology and Social Research 263. Väitöskirja. Jyväskylän yliopisto.

Heimonen. S. (2010). Muistisairaiden ihmisten haavoittuvuus. Teoksessa Sarvimäki, A., Heimonen, S. \& Mäki-Petäjä-Leinonen, A. (toim.), Vanhuus ja haavoittuvuus (s. 60-89). Helsinki: Edita.

Heimonen, S. \& Mäki-Petäjä-Leinonen, A. (2015). Laadukas neuvonta vaatii monipuolista osaamista. Memo, 1/2015, s.21-22. Suomen muistiasiantuntijat ry:n julkaisu.

Heimonen, S. \& Pajunen, H. (toim.) (2012). Mielen terveys vanhuudessa. Helsinki: Edita.

Herring, J. (2009). Loosing it? Loosing what? The law and dementia. Child and Family Law Quarterly, 21(1), 3-29.

Hoppania, H-K. (2015). Care as a site of political struggle. Publications of the Department of Political and Economic Studies 25. Academic dissertation. Helsinki: University of Helsinki.

Hoppania, H-K., Mäki-Petäjä-Leinonen, A. \& Nikumaa, H. (2017). (Un)equal treatment? Elderly care and disability services for people with dementia in Finland. European Journal of Social Security, 19(3), 225-241.

Huhtamäki-Kuoppala, M., Ekola, J. \& Hallikainen, M. (2015). Potilaan ja omaisen tukeminen. Teoksessa Erkinjuntti, T., Remes, A., Rinne, J. \& Soininen, H. (toim.) Muistisairaudet (s. 530-536). Helsinki: Duodecim.

Hänninen, T. \& Heimonen, S. (2012). Kognitiiviset toiminnot - kuntoutuksen ja tuen mahdollisuudet normaalissa ikääntymisessä ja muistisairauksissa. Teoksessa Heimonen, S. \& Pajunen, H. (toim.), Mielen terveys vanhuudessa (s. 211-227). Helsinki: Edita.

Jaworska, A. (1998). Respecting the margins of agency: Alzheimer's patients and the capacity to value. Philosophy and Public Affairs 28:2, 105-138. doi: 10.1111/j.1088-4963.1999.00105.x

Joutsenniemi, K. \& Lipponen, K. (2015). Resilienssi ja posttraumaattinen kasvu. Suomen Lääkärilehti 70(39), 2515-2519.

Jyrkämä, J. (2013). Vanheneminen, arkitilanteet ja toimijuus. Teoksessa Heikkinen E., Jyrkämä J. \&
Rantanen T. (toim.), Gerontologia (s. 421-425). Helsinki: Duodecim.

Kalliomaa-Puha, L. (2014). Slow-go ja no-go -kuluttajat markkinoilla. Teoksessa Mäki-Petäjä-Leinonen, A. \& Nieminen, L. Vanhuus ja oikeus (s. 323-352). Helsinki: Lakimiesliiton kustannus.

Kalliomaa-Puha, L. (2017). Valinnanvapaudesta, valtakirjakuluttajista sekä heikoista ja hauraista asiakkaista. Teoksessa Pohjonen S. \& Noso M. (toim.), Kansalainen keskiöön! Näkökulmia soteuudistukseen (s. 13-22). Kunnallisalan kehittämissäätiön Julkaisu 2.

Kotimaisten kielten keskus. Kielitoimiston sanakirja. Haettu 6.6.2017 osoitteesta:

http://www.kielitoimistonsanakirja.fi/netmot. exe?motportal $=80$

Käypä hoito-suositus (2017). Muistisairaudet. Julkaistu 27.1.2017.

Lagerspetz, E. (2011). Hyvinvoinnin filosofia. Teoksessa Saari, J. (toim.), Hyvinvointi. Suomalaisen yhteiskunnan perusta (s. 79-105). Helsinki: Gaudeamus.

Laki ikääntyneen väestön toimintakyvyn tukemista sekä iäkkäiden sosiaali- ja terveyspalveluista 28.12.2012/980.

Laki potilaan asemasta ja oikeuksista 17.8.1992/785.

Laki sosiaalihuollon asiakkaan asemasta ja oikeuksista 22.9.2000/812.

Langdon S.A., Eagle A. \&Warner,J. (2007). Making sense of dementia in the social world: A qualitative study. Social Science \& Medicine, 64, 9891000. doi:10.1016/j.socscimed.2006.10.029

Mackenzie, C., Rogers, W. \& Dodds, S. (2014). Introduction. Teoksessa Mackenzie, C., Rogers, W. \& Dodds, S. (toim.), Vulnerability: new essays in ethics and feminist philosophy (s. 1-29). Oxford: Oxford University Press.

Manthorpe, J. (2016). The dement in the community: social work practice with people with dementia revisited. Dementia, 15(5), 1100-1111. doi: $10.1177 / 1471301214554810$

Manthorpe, J. \& Iliffe, S. (2005). Timely responses to dementia: exploring the social work role. Journal of Social Work, 5(2), 191-203. doi: $10.1177 / 1468017305054973$

Marshall, V. (2005). Agency, events and structure at the end of the life course. Advances in Life Course Research, 10, 57-91. doi: 10.1016/S1040-2608(05)10002-1

Martela, F. (2014). Onnellisuuksien psykologia. Teoksessa Uusitalo-Malmivaara, L. (toim.), Posi- 
tiivisen psykologian voima (s. 30-62). Jyväskylä: PS-kustannus.

McGee, A. (2014). Best interests determinations and substituted judgement: personhood and precedent autonomy. Teoksessa Foster, C., Herring, J. \& Doron, I. (toim.), The law and ethics of dementia (s. 135-147). Oxford and Portland, Oregon: Hart Publishing.

Moisio, P., Karvonen, S., Simpura, J. \& Heikkilä, M. (toim.) (2008), Suomalaisten hyvinvointi. Helsinki: Sosiaali- ja terveysalan tutkimus- ja kehittämiskeskus.

Moniz-Cook, E. \& Manthorpe, J. (toim.) (2008). Early psychosocial interventions in dementia. Evidence-based practice. London: Jessica Kingsley Publishers.

Murto, J., Kaikkonen, R., Pentala-Nikulainen, O., Koskela, T., Virtala, E., Härkänen, T., Koskenniemi, T., Jussmäki, T., Vartiainen, E. \& Koskinen, S. (2017). Aikuisten terveys-, hyvinvointi-ja palvelututkimus ATH:n perustulokset 2010-2017. Verkkojulkaisu: www.thl.fi/ath

Mustasaari, S. \& Al-Sharmani, M. (2018). Between "official" and "unofficial": discourses of muslim marriage conclusion in Finland. Artikkelikäsikirjoitus arvioitavana, Oxford Journal of Law and Religion.

Mäki-Petäjä-Leinonen, A. (2010). Ajoissa apua avobuollosta - Selvitys yksin asuvan muistisairaan oikeusturvan toteutumisesta. Muistiliiton julkaisusarja 2/2010. Helsinki.

Mäki-Petäjä-Leinonen, A. (2013). Ikääntymisen ennakointi - Vanbuuteen varautumisen keinot. Helsinki:Talentum.

Mäki-Petäjä-Leinonen, A. (2017). Protecting a person with dementia through restrictions of freedom? Notions of autonomy in the theory and practice of elder care. Teoksessa Griffiths, A., Mustasaari, S. \& Mäki-Petäjä-Leinonen, A. (toim.), Subjectivity, citizenship and belonging in law: identities and intersections (s. 146-170). Oxon: Routledge.

Nikumaa, H. (2012). Muistisairas sosiaaliturvan asiakkaana. Muistiliiton julkaisusarja 1/2012. Muistiliitto ry.

Perttola, L. (2017). Asiakkaan etu vanhuspalveluja koskevissa soveltamisohjeissa. Oikeus, 46(1), 8-34.

Pietarinen, J. (1993). Itsemääräämisen periaate. Teoksessa Launis, V. \& Räikkä, J. (toim.), Itsemääräämisoikeus. (s. 97-132). Turku: Turun yliopisto.
Pietilä, M., Heimonen, S., Eloniemi-Sulkava, U., Savikko, N., Köykkä, T., Sillanpää-Nisula, H., Frosti, S. \& Saarenheimo, M. (2010). Kohtaamisia vai ohituksia? Muistisairaiden ihmisten toiseus pitkäaikaisessa laitoshoidossa. Gerontologia, 24(3), 261-266.

Pirttilä,T. (2004). Muistihäiriöisen ja dementoituvan henkilön kuntoutuksen mahdollisuudet. Teoksessa Heimonen, S. \& Voutilainen, P. (toim.), Dementoituvan ibmisen kuntoutuksen lupaus (s. 1121). Helsinki: Tammi.

Pynnönen, K., Törmäkangas, T., Rantanen, T., Tiikkainen, P. \& Kallinen, M. (2018). Effect of a social intervention of choice vs. control on depressive symptoms, melancholy, feeling of loneliness, and perceived togetherness in older Finnish people: a randomized controlled trial. Aging \& $\mathrm{Men}^{-}$ tal Health, 22(1), 77-84. doi:10.1080/13607863.2016.1232367

Raivio, M., Mäki-Petäjä-Leinonen, A., Laakkonen, M-L., Tilvis, R. \& Pitkälä, K. (2008). The use of legal guardians and financial powers of attorney among home-dwellers with Alzheimer's disease living with their spousal caregiver. Journal of Medical Ethics, 34, 882-886.

doi:10.1136/jme.2008.025015

Recommendation CM/Rec (2014). Recommendation of the committee of ministers to member states on the promotion of human rights of older persons. Council of Europe: Committee of Ministers. 19 February 2014. Haettu 1.8.2017 osoitteesta:

http://www.refworld.org/docid/53fdc73e4.html

Rosas, A. (2011). Perus- ja ihmisoikeudet EUoikeudessa. Teoksessa Hallberg, P., Karapuu, H., Ojanen, T., Scheinin, M., Tuori, K. \& Viljanen, V-P. (toim.), Perusoikeudet (s. 197-213). Helsinki: WSOYpro.

Ryan, R.M. \& Deci, E.L. (2000). Self-determination theory and the facilitation of intrinsic motivation, social development, and well-being. American Psychologist, 55, 68-78.

doi:10.1037/0003-066X.55.1.68

Saarenheimo, M. (2013). Mielenterveys. Teoksessa Heikkinen, E., Jyrkämä,J. \& Rantanen, T.(toim.), Gerontologia, 3. uudistettu painos (s. 373-380). Helsinki: Duodecim.

Saarenheimo, M. \& Pietilä, M. (2006). Omaishoito ja palvelujärjestelmä. Teoksessa Eloniemi-Sulkava, U., Saarenheimo, M., Laakkonen, M-L., Pietilä, 
M., Savikko, N., Pitkälä, K. (toim.), Omaishoito ybteistyönä. Iäkkäiden dementiaperheiden tukimallin vaikuttavuus (s. 68-80). Tutkimusraportti 14. Helsinki: Vanhustyön keskusliitto.

Saari,J. (2011). Hyvinvoinnin kentät. Teoksessa Saari, J. (toim.), Hyvinvointi. Suomalaisen yhteiskunnan perusta (s. 33-78). Helsinki: Gaudeamus.

Sarvimäki, A. \& Stenbock-Hult, B. (2010). Vanhuus, haavoittuvuus ja hoidon eettisyys. Teoksessa Sarvimäki, A., Heimonen, S. \& Mäki-Petäjä-Leinonen, A. (toim.), Vanhuus ja haavoittuvuus (s. 3358). Helsinki: Edita.

Seligman, M. (2011). Flourish: a visionary new understanding of happiness and well-being. New York: Free Press.

Sosiaalihuoltolaki 30.12.2014/1301.

STM (2012). Kansallinen muistiohjelma 2012-2020. Tavoitteena muistiystävällinen Suomi. Sosiaali- ja terveysministeriön raportteja ja muistioita 2012:10. Helsinki: Sosiaali- ja terveysministeriö.

STM (2013). Laatusuositus hyvän ikääntymisen turvaamiseksi ja palvelujen parantamiseksi. Sosiaalija terveysministeriön julkaisuja 2013:11. Helsinki: Sosiaali- ja terveysministeriö.

Suomen perustuslaki 11.6.1999/731.

Tanner, D. (2011). Identity, selfhood and dementia: messages for social work. European Journal of Social Work, 16(2), 155-170. doi: 10.1080/13691457.2011.611795

THL (2016). Vanhuspalvelujen seurantatutkimus. Haettu 7.11.2017 osoitteesta: https://www.thl.fi/fi/web/ikaantyminen/toimivat-vanhuspalvelut/vanhuspalvelujen-tila/vanhuspalvelujen-tila-maakunnissa

Terveydenhuoltolaki 30.12.2010/1326.

Topo, P. (2012). Autonomia on arkinen asia. Memo 3, 9-10.

Tuori, K. \& Kotkas, T. (2016). Sosiaalioikeus. Helsinki: TalentumPro.
Turner, R.J. (1981). Social support as a contingency in psychological well-being. Journal of Health and Social Behavior, 22(4), 357-367. Haettu 1.8.2017 osoitteesta:

https://www.jstor.org/stable/pdf/2136677.pdf?refreqid=excelsior\%3Aa372a57f0479f449583 3fd70f9d05b27

UEF oikeustieteet (2017). Valtakunnalliset $\mathrm{Hy}_{-}$ vinvointioikeuden päivät Joensuussa. Haettu 6.6.2017 osoitteesta:

https://www.uef.fi/web/oikeustieteet/hyvinvointioikeuden-paivat

Uoti, A. (2003). Taloudelliset, sosiaaliset ja sivistykselliset perusoikeudet kunnallisessa päätöksenteossa. Tutkimus lasten byvinvointipalvelujen oikeudellisesta objauksesta ja valvonnasta. Acta Universitatis Tamperensis 911, Tampere: Tampereen yliopisto. Werner, P. \& Doron, I. (2016). The legal system and Alzheimer's disease: social workers and lawyers' perceptions and experiences. Journal of Gerontological Social Work, 59(6), 478-491. doi: 10.1080/01634372.2016.1239235.

WHO (2005). Promoting mental health. Concepts, emerging evidence, practice. Geneva: World Health Organization.

WHO (2013). Investing in mental health. Evidence for action. Geneva: World Health Organization. Haettu osoitteesta: http://www.who.int/mental_ health/media/investing_mnh.pdf

WHO (2014). Social determinants of mental health. Geneva: World Health Organization.

Viramo, P. \& Sulkava, R. (2015). Muistisairauksien epidemiologia. Teoksessa Erkinjuntti, T., Remes, A., Rinne, J. \& Soininen, H. (toim.), Muistisairaudet (s. 35-43). Helsinki: Duodecim.

Virkola, E. (2014). Toimijuutta, refleksiivisyyttä ja neuvotteluja - muistisairaus yksinasuvan naisen arjessa. Jyväskylä Studies in Education, Psychology and Social Research 491. Väitöskirja. Jyväskylän yliopisto. 